\title{
New occurrence records of Bromeliaceae for the state of Maranhão, northeastern Brazil
}

\author{
Elidio A. E. Guarçoni ${ }^{1}$, Jeferson D. S. Sousa ${ }^{1}$, Alessandro W. C. Ferreira ${ }^{2}$, Wagner R. S. Junior ${ }^{2}$, \\ Miguel S. Oliveira ${ }^{3}$, Eduardo O. Silva ${ }^{4}$
}

1 Maranhão Continental Herbarium, Federal University of Maranhão, Coordination of Natural Sciences Biology, Bacabal Campus, Av. Governador João Alberto, s/n, Bambu, CEP 65700-000, Bacabal, MA, Brazil. 2 Federal University of Maranhão, Department of Biology, University City Dom Delgado, Av. dos Portugueses, 1966, Bacanga, CEP 65080-805, São Luís, MA, Brazil. 3 State University of Maranhão, Department of Chemistry and Biology, Praça Duque de Caxias, s/n, Morro do Alecrim, CEP 65604-090, Caxias, MA, Brazil. 4 Federal University of Maranhão, Coordination of Natural Sciences, Codó Campus, Av. Dr. José Anselmo, 2008, São Benedito, CEP 65.400-000, Codó, MA, Brazil.

Corresponding author: Elidio A. E. Guarçoni, elidio.guarconi@ufma.br

\begin{abstract}
We report three species of Bromeliaceae (Encholirium spectabile Mart. ex Schult. \& Schult.f., Pitcairnia burchellii Mez, and Tillandsia bulbosa Hook.) for the first time from Maranhão, northeastern Brazil, based on our fieldwork. Data on species' morphology, taxonomy, ecology, and geographic distribution are included. Our new data add to the knowledge to the flora of Maranhão and expand the distribution of three bromeliad species in Brazil.
\end{abstract}

\section{Keywords}

Encholirium spectabile, geographic distribution, Pitcairnia burchellii, taxonomy, Tillandsia bulbosa

\section{Introduction}

Biogeography is the study of the distribution of living beings in space and time, and distribution patterns can be used to propose hypotheses on the processes of biotic regionalization around the world (Carvalho and Almeida 2016). Biogeographic data are needed for the effective conservation measures of species in natural environments and also provide important biological information (Primack and Rodrigues 2001).

The state of Maranhão, in northeastern Brazil, has a large area (IBGE 2017) occupying a strategic position at confluence the Amazon, Cerrado, and Caatinga domains; thus, the state presents several types of plant formations and the flora is highly diverse (Muniz 2006; Dias et al
2009). Although Marahnão exhibits floristic potential, few studies on Bromeliaceae and other families of plants in the state are available, as shown by recently published new occurrences (e.g. Ferreira et al. 2018; Guarçoni et al. 2018; Ferreira et al. 2019a, 2019b; Salazar-Ferreira et al. 2020; Silva et al. 2020) and new species (e.g. Scatigna et al. 2019; Guarçoni et al. 2020).

During recent fieldwork throughout Maranhão, we collected three species belonging to the family Bromeliaceae, Encholirium spectabile Mart. ex Schult. \& Schult. f., Pitcairnia burchellii Mez, and Tillandsia bulbosa Hook. All were previously known only from other states in Brazil, and we report these three species for the first 
time from Maranhão (Flora do Brasil 2020). We include our new data, as well as comments on these species' morphology, taxonomy, and ecology.

\section{Methods}

Study location. The state of Maranhão, in northeastern Brazil, occupies an area of $331,983 \mathrm{~km}^{2}$. The state's vegetation displays ecotonal characteristics due to its position between the Amazon (North Region of Brazil), Cerrado (Midwest Region), and Caatinga (Northeast Region) domains (Muniz 2006). The climate of Maranhão is Tropical Savânico Aw and Tropical Monçônico Am (Köppen 1948), with average annual temperature ranging between 22 and $27^{\circ} \mathrm{C}$ and average annual precipitation between 800 and $2800 \mathrm{~mm}$ (Martins and Oliveira 2011). The dry period lasts from June to November or December when there is a water deficit of 150-300 mm, and the rainy period occurs between January and June, but more intense in February and March (IMESC 2008).

Data collection. We made field collections between June 2015 and December 2019. The specimens were herborized according to the methology of Fidalgo and Bononi (1989), and the voucher specimens have been incorporated in the BMA, INPA, SLUI, and UB herbaria (acronyms according to Thiers 2020). Author names of each species are in agreement with IPNI (2019).

The geographic distributions of the three species included here are in accordance with Flora do Brasil (2020) and SpeciesLink (2020). The map of the new records (Fig. 1) was created using QGIS v. 2.18.12 software (QGIS.org 2020), using SIRGAS 2000 data.

\section{Results}

Encholirium spectabile Mart. ex Schult. \& Schult. f., in Syst. Veg., 7(2): 1233. (Roemer and Schultes 1830) Figure $2 \mathrm{~A}-\mathrm{C}$

New records. BRAZIL - Maranhão • V.P. Lima 6898 (INPA 205251, UB45-40-95); Carolina, na estrada Caro-

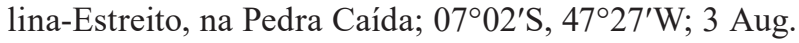
1993; fr. • E. Guarçoni 2342 \& A.W.C. Ferreira (BMA 1042); Fortaleza dos Nogueiras, subida da Agrosserra; 06 $52^{\prime} 50^{\prime \prime} \mathrm{S}, 045^{\circ} 57^{\prime} 19^{\prime \prime} \mathrm{W}$; 6 Jun. 2015; fl.

Identification. Herb 1.1-2.0 m tall, rupicolous. Leaves ca 20, patents upright, curved at upper third portion; sheath elliptical, $2.8-4.7 \times 3.5-5.9 \mathrm{~cm}$, white, glabrous, margin entire; blade linear-triangular, 55.8-91.0 × 1.9-0.6 cm, green, cinereous on both faces, margin aculeate, aculeos green, ca $1.5-0.3 \mathrm{~mm}$ long, narrowing to apex. Peduncle erect, $47.0-57.5 \mathrm{~cm}$ long, green to brown, glabrous. Peduncle bracts medians exceeding internodes, lanceolate, $4.2-15.5 \times 0.4-1.0 \mathrm{~cm}$, vinaceous at base, cinereous or straw-like at apex, glabrous to sparingly lepidote margin aculeate, aculeus ca $1.5 \mathrm{~mm}$ long, apex attenuated. Inflorescence raceme $35.7-36.0 \mathrm{~cm}$ tall; rachis

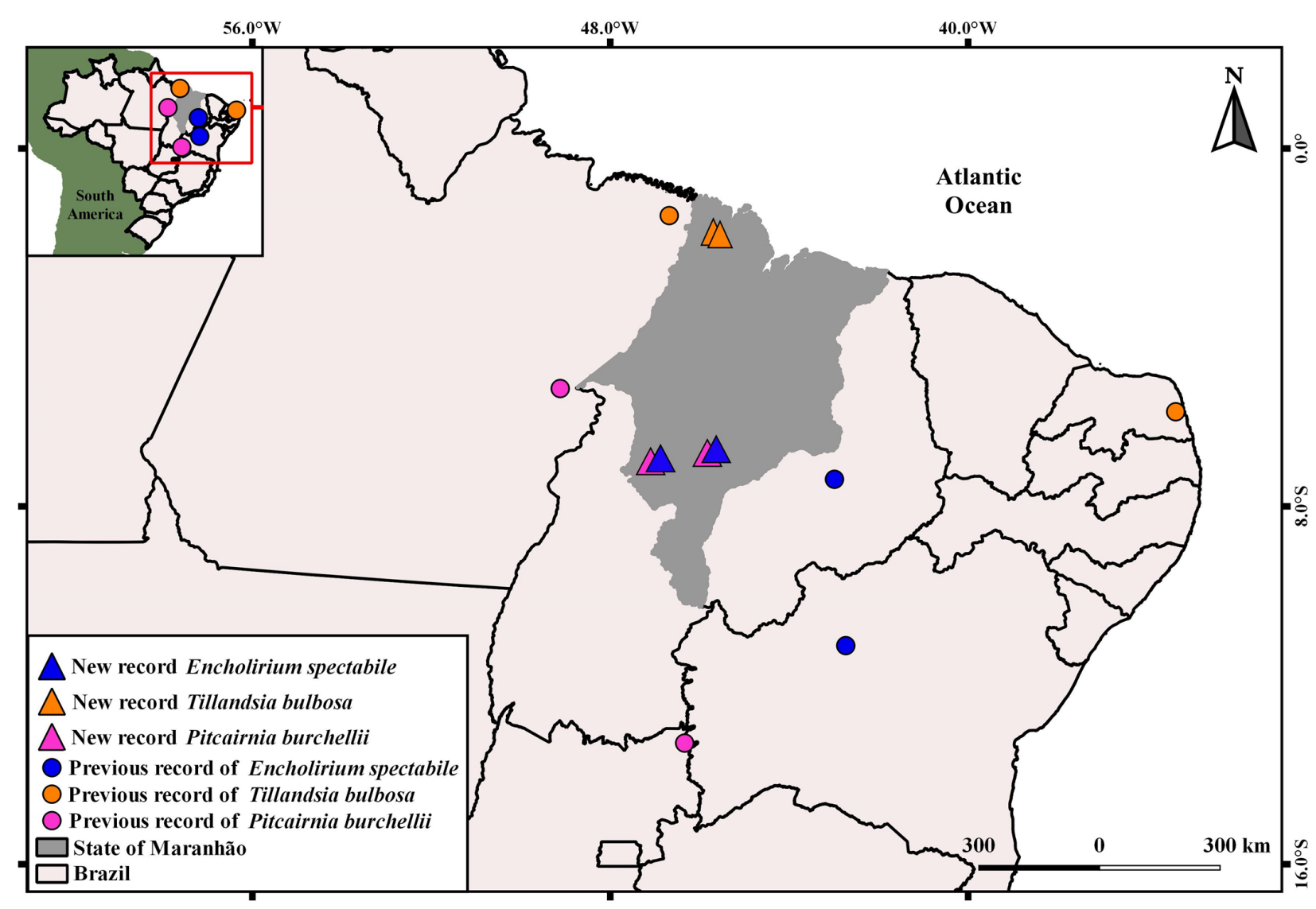

Figure 1. Geographic distribution of Encholirium spectabile Mart. ex Schult. \& Schult. f. (blue triangle), Pitcairnia burchellii Mez (hot pink triangle) and Tillandsia bulbosa Hook. (orange triangle) in the state of Maranhão, Brazil. 

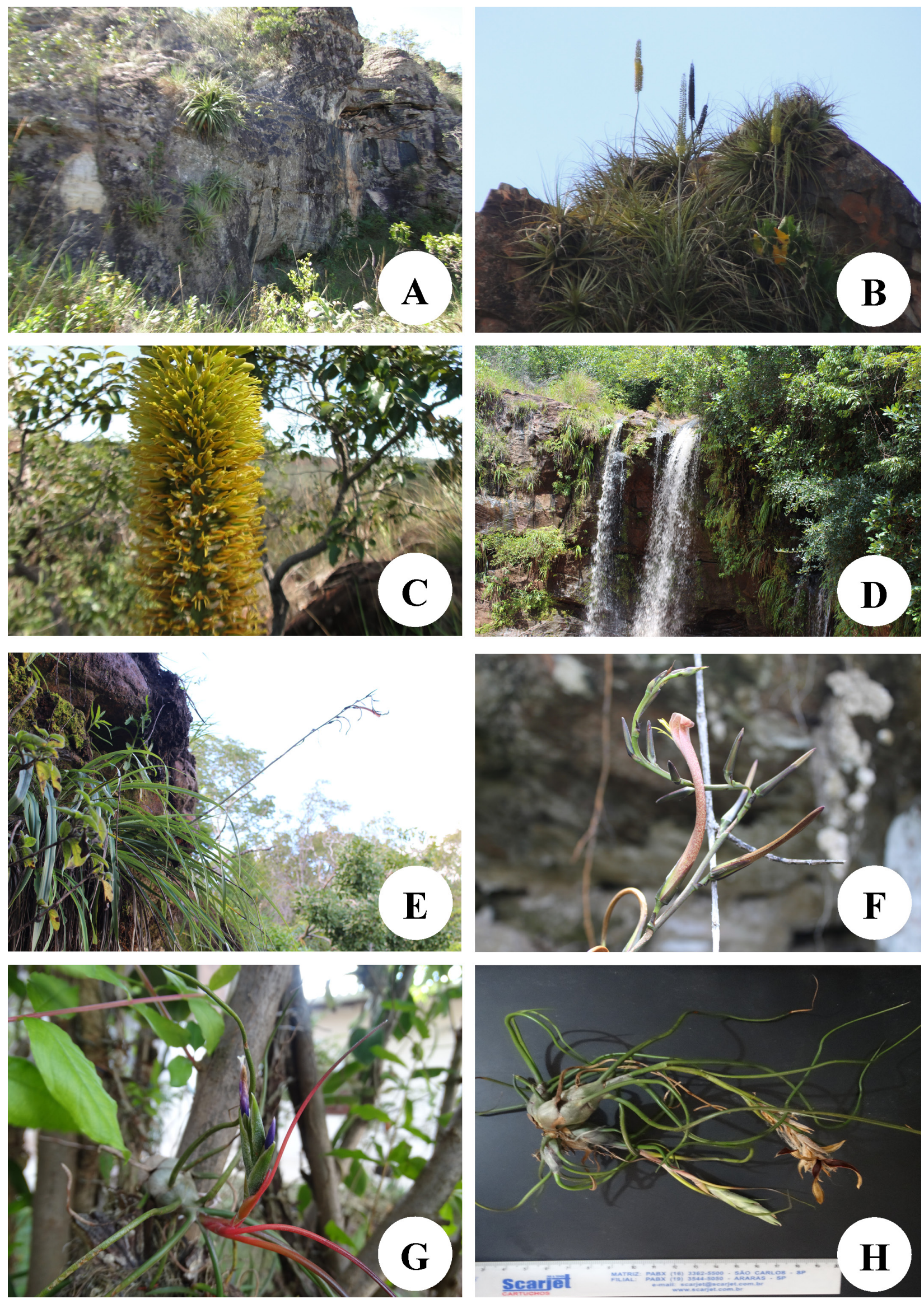

Figure 2. New occurrences of Bromeliaceae from Maranhão. A-C. Encholirium spectabile Mart. ex Schult. \& Schult. f.: (A) natural environment habit; (B) rosettes in bloom and fruiting; (C) details of the inflorescence. D-F. Pitcairnia burchellii Mez.: (D) in the natural environment at the Fortaleza dos Nogueiras city; (E) flowering plant habit in the of Carolina city, PARNA Chapada das Mesas; (F) flower detail. G, H. Tillandsia bulbosa Hook.: (G) plant in bloom in the Cândido Mende city; (H) details of the plant. (Photos: A-F: Elidio Guarçoni; G, H: Alessandro Ferreira). 
green, glabrous. Floral bract oval-lanceolate, $0.3-0.5 \times$ 0.1-0.2 cm, brown to blackish, glabrous, margin entire, apex attenuated. Flowers more than 50, pedicellate, patents, $1.7-2.1 \mathrm{~cm}$ long; pedicel $1.0-1.2 \mathrm{~cm}$ long, green to brown, glabrous; sepals ovals, 0.7-0.9 × 0.3-0.4 cm, green with apex vinaceous, glabrous, apex acute; petals elliptical, $1.6-1.8 \times 0.4-1.0 \mathrm{~cm}$, green or greenishcream, glabrous, apex obtuse; petal appendages absent; stamens exserted, free, yellowish green; filaments 1.5$2.1 \mathrm{~cm}$ long; anthers linear, green, dorsifixed; ovary inferior, 0.7-1.3 cm long; style 1.4-1.7 cm long; stigma ca $0.9 \mathrm{~mm}$, yellow. Fruit unknown.

Pitcairnia burchellii Mez, Fl. Peruv. 3: 35. (Mez 1894) Figure 2D-F

New records. BRASIL - Maranhão • E. Guarçoni et al. s/n. (BMA 2095); Carolina, National Park Chapada das Mesas, subida da Serra Grande; 06 $55^{\prime} 53^{\prime \prime}$, 047²2'50"W; 15 Feb. 2019; fl. • E.O. Silva et al. 205 (SLUI 5813); Fortaleza dos Nogueiras, Cachoeira Recanto das Águias; 06 $57^{\prime} 23^{\prime \prime} \mathrm{S}, 046^{\circ} 00^{\prime} 11^{\prime \prime} \mathrm{W} ; 15$ Jun. 2017; fl.

Identification. Herb $53.3-91.2 \mathrm{~cm}$ tall, terrestrial or saxicolous. Leaves ca 12, dimorphic, suberect; sheath ovate, $0.8-3.1 \times 1.2-1.8 \mathrm{~cm}$, green, white-lepidote abaxially, margin entire; blade linear, 48.2-87.6 × 1.7-2.0 cm, green, densely white-lepidote abaxially, glabrous adaxially, channeled, margin entire with aculeos at base, aculeos brown, ca $2 \mathrm{~mm}$ long, apex acute. Peduncle erect to suberect, 47.6-89.4 cm long, green, white-lanuginous. Peduncle bracts larger than internodes, linear, 16.0-25.8 $\times 0.5-0.7 \mathrm{~cm}$, green, densely white-lepidote on abaxial face, glabrous on adaxial face, margin entire, apex acute. Inflorescence simple, $10-11.6 \mathrm{~cm}$ tall; rachis brown, white-lanuginous. Floral bracts, ovate, 2.7-5.8 × 2.7-3.4 $\mathrm{mm}$, brown, white-lepidote on abaxial face, glabrous on adaxial face, margin entire, apex acute. Flowers 7-10, pedicellate, suberect, 4.9-5.3 cm long; pedicel 5.1-6.7 $\mathrm{mm}$ long, brown, white-tomentose; sepals linear, 1.7-1.8 $\times 0.5 \mathrm{~cm}$, brown, densely white-tomentose, fimbriated, succulent, apex acute; petals linear, 4-4.5 × 0.4-0.5 cm, reddish-green, glabrous, presence of a pair of petal appendages, apex acute; petal appendages ovate, $2.1 \mathrm{~mm}$ long, yellow, truncated; stamens included, free, yellow; filaments ca $2 \mathrm{~cm}$ long; anthers oblong, yellow, dorsifixed; ovary superior, ca $6.3 \mathrm{~mm}$ long; style ca $2.7 \mathrm{~cm}$ long; stigma $2.2 \mathrm{~mm}$ long, yellow. Fruit capsule; seeds unknown.

Tillandsia bulbosa Hook., in Exot. Fl. 3: 173. (Hooker 1825)

Figure 2G, H

New records. BRAZIL - Maranhão • W.R. SilvaJúnior \& A.W.C. Ferreira 206 (SLUI 5814); Cândido Mendes, Fazenda Sete Irmãos, igarapé Reno; 0152'61"S, 04545'33"W; 29 Jul. 2018; fl. • A.W.C. Ferreira 207 (SLUI 5815); rio Macaxeira; 0152'47"S, 04547'54"W; 20 Dec. 2019; fl.
Identification. Herb $10-18 \mathrm{~cm}$ tall, epiphyte. Leaves 8-14, arched to winding; sheath somewhat pentagonal when dry, 2.0-2.6 × 1.7-2.1 cm, green, cinereous-lepidote, margin entire; blade linear, $8.3-12.8 \times 0.3-0.5 \mathrm{~cm}$, green, sparsely lepidote on both faces, margin entire, apex attenuate. Peduncle incurved, 3-7 cm long, green, cinereous-lepidote. Peduncle bracts exceeding internodes, elliptic at base, $2.0-15.0 \times 0.5-0.6 \mathrm{~cm}$, green to rosaceous, involute-subulate towards apex, sparse-lepidote, margin entire, apex long acuninate. Inflorescence spike, $8-10 \mathrm{~cm}$ long; rachis green, glabrous. Floral bracts elliptical, $0.1-0.2 \times 0.5-0.6 \mathrm{~cm}$, green, lepidote, margin serrated, apex acute to acuminate. Flowers 3-6, sessile, suberect, $1.3-1.8 \times 0.2-0.5 \mathrm{~cm}$, congested; pedicel absent; sepals elliptical-oblong, $1.6-1.7 \times 0.3-0.4 \mathrm{~cm}$, purple, glabrous, subconate, apex acute; petals ellipticallanceolate, ca $3.0 \times 0.5 \mathrm{~cm}$, purple, glabrous, apex subacute; petal appendages absent; stamens exserted, free, green; filaments ca $3.3 \mathrm{~cm}$ long, compressed; anthers linear, yellow, basifixed; ovary superior, $0.5 \mathrm{~cm}$ long; style $2.4-2.5 \times 0.1 \mathrm{~cm}$; stigma ca $0.1 \mathrm{~cm}$ long, green. Fruit capsular, 3.6-3.9 $\times 0.3 \mathrm{~cm}$, cylindrical; seeds elongate, $0.2 \mathrm{~cm}$ long, dark brown, feathery appendages 2.0-2.5 cm long.

\section{Discussion}

Encholirium spectabile, described by Schultes \& Schultes f. in 1830 (Smith and Downs 1974; Forzza 2001), displays a wide geographical distribution and high morphological variability which have contributed to the description of the extremes of its variations to be considered as distinct species (Forzza 2001). Encholirium spectabile is endemic to Brazil, found in the Caatinga, Cerrado, and Atlantic Forest domains, in the states of Goiás, Minas Gerais, Alagoas, Bahia, Ceará, Paraíba, Pernambuco, Piauí, Rio Grande do Norte, and Sergipe (Flora do Brasil 2020; SpeciesLink 2020). Our records of this species are the first occurrences of any species of Encholirium in Maranhão, which until now was the only state in northeastern Brazil where this genus had not been recorded (Flora do Brasil 2020). Encholirium spectabile has the largest geographic distribution in Brazil of any species of Encholirium; this species is found on rocky outcrops throughout almost all of northeastern Brazil, mainly in Caatinga areas, although it can also be found in the rocky fields of the mountain located north of the Cadeia do Espinhaço, in Bahia, and in CaatingaCerrado transition outcrops (Forzza 2001). The species is categorized as Least Concern according to International Union for the Conservation of Nature (IUCN) criteria (Romand-Monnier 2013).

At the sites where we found this species, it is rupicolous and saxicolous on outcrops of sedimentary rocks in the Cerrado domain, with a strong influence from the Amazon domain. We observed this species either isolated or forming clumps containing a few individuals. It was always a heliophile, blooming between June and 
July. Our records of E. spectabile expand the geographic distribution of this species $338 \mathrm{~km}$ west of Sete Cidades (Piauí, Brazil) and $588 \mathrm{~km}$ north of São Inácio (Bahia, Brazil), the nearest previously known occurrences.

Pitcairnia burchellii is extremely similar to Pitcairnia lanuginosa Ruiz \& Pav. and is considered a synonym (Smith and Downs 1974). However, despite its close resemblance, " $P$. burchellii is more robust than $P$. lanuginosa", which does not occur in Brazil (Saraiva 2013; Saraiva et al. 2015). Pitcairnia burchellii is endemic to Brazil, where it occurs in the Amazon, Atlantic Forest, Caatinga, and Cerrado domains. It presents one of the greatest distributions within the genus, occurring throughout the Cerrado domain, where it occurs in some outcrop areas in the North (Pará, Rondônia, Tocantins), Northeast (Alagoas), Midwest (Goiás, Mato Grosso do Sul, Mato Grosso) and Southeast (Minas Gerais) (Flora do Brasil 2020) regions.

Pitcairnia bruchellii is registered for the first time for Maranhão and has its second record for the northeast of Brazil; previously it has been recorded only in Alagoas but with possible occurrences in Bahia and Piaui (Flora do Brasil 2020). In Maranhão, we collected P. burchellii in the cities of Fortaleza dos Nogueiras and Carolina (Chapadas das Mesas National Park), always near the water in the rocky outcrops of the Cerrado domain. We found blooming during February and March. This species has not yet been evaluated by the IUCN (2020). Our records of $P$. burchellii expand its geographic distribution by $713 \mathrm{~km}$ north of São Domingos (Lapa river, Terra Ronca State Park, Goiás, Brazil) and $387 \mathrm{~km}$ east of Carajás (Serra North, N-1 ore exploration area, Marabá, Pará, Brazil).

Tillandsia bulbosa has a morphology distinctive from other species of its genus and can be easily recognized by its bulb-like rosettes. Tillandsia bulbosa is widely distributed, occurring from Mexico to Brazil. In Brazil it occurs in the Amazon and Atlantic domains, in the North (Amazonas, Amapá, Pará), Northeast (Alagoas, Bahia, Paraíba, Pernambuco, Rio Grande do Norte, Sergipe), and Southeast (Espírito Santo) regions (Flora of Brazil 2020). Our new records are the first occurrences from Maranhão (Flora of Brazil 2020). We found this species in the municipality of Cândido Mendes, in an area of Amazon domain area. It is an epiphyte, blooming between July and December.

Where we found T. bulbosa, specimens develop both in the crown and in the phorophyte stem of the forest fragment, near riverbanks and seasonal streams. It was common to find ants nesting among the dilated leaf sheaths of this bromeliad. Capuchin monkeys (Sapajus sp.) were observed feeding on the leaf bases of T. bulbosa. These associations have also been verified by Fiorato (2009) and (Benzing) 1990). Our new records of $T$. bulbosa extend the geographic distribution of this species by $88 \mathrm{~km}$ east of Viseu (Pará, Brazil) and 1,240 km west of Macaíba (Rio Grande do Norte, Brazil).

\section{Acknowledgments}

We thank FAPEMA (UNIVERSAL-00855/17) for funding our research, as well as the Chico Mendes Institute (ICMBIO 23683-6) and the State Secretariat of Environment of the Maranhão State, Biodiversity and Protected Areas Superintendence (SBAP 0203724/2015) for the granting of collection licenses. AWFC thanks FAPEMA (UNIVERSAL-0040/2015). We also acknowledge the anonymous reviewers who made valuable suggestions to improve the manuscript.

\section{Authors' Contributions}

EAEG collected and identified part of the material, reviewed the manuscript, prepared the figures and is responsible for the project. JDSS collected, helped with the identification of the material and was responsible for writing the manuscript. AWCF collected and identified some of the material and revised the article. MSO collected part of the material, revised the article and prepared the map. WRSJ collected and identified part of the material and revised the manuscript. EOS collected some of the material and revised the manuscript.

\section{References}

Benzing DH (1990) Vascular epiphytes, general biology and related biota. Cambridge University Press, Cambridge, UK, 354 pp.

Carvalho JB, Almeida EAB (2016) Biogeografia da América do Sul: análise de tempo, espaço e forma. 2 editção. Roca, Rio de Janeiro, Brazil, 324 pp.

Dias PAD, Santos CLC, Rodrigues FS, Rosa LC, Lobato KS, Rebêlo JMM (2009) Espécies de moscas ectoparasitas (Diptera, Hippoboscoidea) de morcegos (Mammalia, Chiroptera) no estado do Maranhão. Revista Brasileira Entomologia 53: 128-133.

Ferreira AWC, Oliveira MS, Silva Junior WR, Andrade IM, Coelho MAN, Oliveira HC, Mayo SJ (2019a) New occurrences of small aquatic duckweeds (Araceae, Lemnoideae) in Maranhão state, northeastern Brazil. Check List 15: 1153-1160. https://doi.org/10. 15560/15.6.1153

Ferreira AWC, Oliveira MS, Engels ME, Pessoa E (2019b) Found in Brazil again! Expanding the distribution of Maxillaria aureoglobula Christenson (Orchidaceae, Maxillariinae) and a key to the species of Maxillaria sect. Rufescens Christenson from Brazil. Check List 15: 1107-1112. https://doi.org/10.15560/15.6.1107

Ferreira AWC, Calió MF, Silva Junior WR, Silva MJC, Oliveira MS, Silva EO, Guarçoni EAE, Carvalho AKC, Figueiredo N (2018) First record of Voyria caerulea Aubl. (Gentianaceae), a mycoheterotrophic plant, in Maranhão state, northeastern Brazil. Check List 14: 833-837. https://doi.org/10.15560/14.5.833

Fidalgo O, Bononi VLR (1989) Técnicas de coleta, preservação de material botânico. Série Documentos. Instituto de Botânica, São Paulo, Brazil, 62 pp.

Fiorato L (2009) O gênero Tillandsia L. (Bromeliaceae) no Estado da Bahia, Brasil. PhD dissertationm Universidade de São Paulo, São Paulo, Brazil, 107 pp.

Flora do Brasil (2020 under construction). Jardim Botânico do Rio de Janeiro. http://floradobrasil.jbrj.gov.br/ . Acessed on: 2020-03-08.

Forzza RC (2001) Filogenia da tribo Puyeae Wittm. e revisão taxonômica do gênero Encholirium Mart. ex Schult. \& Schult. F. (Pitcairnioideae-Bromeliaceae). PhD dissertation, Universidade de São Paulo, São Paulo, Brazil, 208 pp. 
Guarçoni EAE, Saraiva RVC, Ferraz TM (2020) Dyckia maranhensis (Bromeliaceae, Pitcairnioideae), a new species from the Cerrado of Maranhão, northeastern Brazil. Systematic Botany 45: 47-52. https://doi.org/10.1600/036364420X15801369352289

Guarçoni EAE, Costa AF, Silva EO, Ferreira AWC, Oliveira MS (2018) New records of Tillandsia L. (Bromeliaceae, Tillandsioideae) for Maranhão state, Brazil. Check List 14: 951-959. https:// doi.org/10.15560/14.6.951

Hooker, WJ (1825) Exotic flora: containing figures and descriptions of new, rare, or otherwise interesting exotic plants, especially of such as are deserving of being cultivated in our gardens; together with remarks upon their generic and specific characters, natural orders, \&c. Vol. III (Part XXVI). William Blackwood, Edinburgh.

IBGE (2017) Cidades e estados do Brasil. https://cidades.ibge.gov.br/ brasil/ma/panorama. Accessed on: 2020-4-4

IMESC (2008) Perfil do Maranhão 2006/2007. Instituto Maranhense de Estudos Socioeconômicos e Cartográficos, São Luís, Brazil. http://imesc.ma.gov.br/portal/Post/view/outras-publicacoes/38. Accessed on: 20-4-26.

IPNI (2020) International plant names index. The Royal Botanic Gardens, Kew / Harvard University Herbaria \& Libraries, Cambridge, USA / Australian National Botanic Gardens, Canberra, Australia. http://www.ipni.org. Accessed on: 2020-10-17.

IUCN (2020) The IUCN Red List of threatened species, version 2020.2. International Union for the Conservation of Nature, Cambridge, UK. https://www.iucnredlist.org. Accessed on: 2020-426.

Köppen WP (1948) Climatologia: con un estudio de los climas de la tierra. Fondo de Cultura Econômica, Mexico City, Mexico, 478 p.

Martins MB, Oliveira TG (2011) Amazônia maranhense: diversidade e conservação. Belém. Museu Paraense Emílio Goeldi, Belém, Brazil, 328 pp.

Mez C (1894) Bromeliaceae. In: Martius CFP von, Eichler AG, Urban I (Eds). Flora Brasiliensis 3(3). F. Fleischer, Leipzig, 173-634.

Muniz FH (2006) A vegetação da região de transição entre a Amazônia e o Nordeste: diversidade e estrutura. In: de Moura EG. (Ed.) Agro ambientes de transição entre o trópico úmido e o semiárido do Brasil: atributos, alterações e uso na produção familiar. 2 nd ed. Programa de Pós-graduação em Agroecologia/UEMA, São
Luís, Brazil, 53-69.

Primack RB, Rodrigues E (2001) Biologia da Conservação. Ed. Planta, Londrina, Brazil, 327 pp.

QGIS.org (2020) QGIS. https://www.qgis.org/pt BR/site/index.html. Accessed on: 2020-3-18.

Roemer JJ, Schultes JA (1830) Systema vegetabilium, ed. 15 bis. J.G. Cottae, Stuttgart, $1061 \mathrm{pp}$

Romand-Monnier F (2013) Encholirium spectabile. The IUCN Red List of threatened species 2013. https://doi.org/10.2305/IUCN. UK.2013-2.RLTS.T44393680A44499793.en. Accessed on: 20204-25.

Salazar-Ferreira M, Gonella PM, Guarçoni EAE (2020) New records of Utricularia (Lentibulariaceae) for the state of Maranhão, Brazil. Check List 16: 121-125. https://doi.org/10.15560/16.1.121

Saraiva DP (2013) Filogenia morfológica de Pitcairnia L'Hér. (Pitcairnioideae - Bromeliaceae). PhD dissertation, Instituto de Pesquisas Jardim Botânico do Rio de Janeiro, Rio de Janeiro, Brazil, $79 \mathrm{pp}$.

Saraiva DP, Mantovani A, Forzza RC (2015) Insights into the evolution of Pitcairnia (Pitcairnioideae-Bromeliaceae), based on morphological evidence. Systematic Botany 40: 726-736. https://doi. org/10.1600/036364415X689186

Scatigna AV, Brandão CM, Colletta GD, Teles RM, Cavalcante KSB, Souza VC, Simões AO (2019) Dizygostemon riparius (Plantaginaceae, Gratioleae), a new species from Maranhão, northeastern Brazil. Willdenowia 49: 177-186. https://doi.org/10.3372/wi. 49.49206

Silva EO, Milward-de-Azevedo MA, Ferreira AWC, Sobral MEG (2020) Rediscovery and new records of Passiflora auriculata Kunth and $P$. cisnana Harms (Passifloraceae) in Brazil. Check List 16: 441-450. https://doi.org/10.15560/16.2.441

Smith LB, Downs RJ (1974) Flora Neotropica, Monograph 14 (1). Pitcairnioideae (Bromeliaceae). Hafner Press, New York, USA, 658 pp.

SpeciesLink (2020) Base de dados eletrônica. http://www.splink.org. br. Accessed on: 2020-4-25.

Thiers B (2020) Index herbariorum: a global directory of public herbaria and associated staff. New York Botanical Garden's Virtual Herbarium. http://sweetgum.nybg.rg/science/ih/. Accessed on: 2020-4-1. 